\title{
25 Research Soure \\ Effect Size of Rituximab on Pulmonary Function in the Treatment of Connective-Tissue Disease-Related Interstitial Lung Disease: A Systematic Review and Meta-Analysis
}

\author{
Yuanchen Zhao \\ Guang'anmen Hospital \\ Yang Gao \\ Guang'anmen Hospital \\ Tananchai Petnak \\ Mayo Clinic Rochester \\ Wisit Cheungpasitporn \\ Mayo Clinic Rochester \\ Charat Thongprayoon \\ Mayo Clinic Rochester \\ Xing Zhang \\ Guang'anmen Hospital \\ Teng Moua ( $\nabla$ moua.teng@mayo.edu )
}

Mayo Clinic Rochester

\section{Research}

Keywords: rituximab, connective-tissue disease related interstitial lung disease, meta-analysis, systematic review

Posted Date: September 7th, 2021

DOI: https://doi.org/10.21203/rs.3.rs-837872/v1

License: (c) (1) This work is licensed under a Creative Commons Attribution 4.0 International License. Read Full License 


\section{Abstract}

BACKGROUND: Rituximab (RTX) has been previously reported as directed treatment in patients with connective-tissue disease-related interstitial lung diseases (CTD-ILD). A systematic assessment of treatment effect size on pulmonary function outcomes and related adverse effects in patients with CTD-ILD has not been previously reported.

METHODS: We performed a systematic review and meta-analysis of published reports from PubMed, Embase, and Cochrane Libraries. Randomized and nonrandomized controlled trials, case-control, cohort, and case series (with five or more cases) containing individual pulmonary function data and adverse effects were included. Study endpoints were pre and post treatment change in percent predicted forced vital capacity (FVC \%) and diffusion capacity for carbon monoxide (DLCO\%), along with reported drug-related adverse events.

RESULTS: Twenty studies totaling 411 patients were identified with 14 included in the meta-analysis of pulmonary function and six in the descriptive review. Random effects meta-analysis of pre and post-treatment pulmonary function findings demonstrated increases in FVC\% ( $n=296)$ (mean difference (MD) 4.57\%, [95\% Cl 2.63-6.51]) and DLCO\% ( $\mathrm{n}=246)(\mathrm{MD} 5.0 \%$ [95\% Cl 2.71-7.29]) after RTX treatment. RTX treatment-related adverse effects were reported in $13.6 \%$ of the pooled cohort.

CONCLUSIONS: A systematic assessment of post-treatment effect size suggests a potential role for RTX in stabilizing or improving lung function in patients with CTD-ILD, with a modest but not insignificant adverse effect profile.

\section{Introduction}

The connective-tissue diseases (CTD) are commonly associated with initial or subsequent interstitial lung disease, frequently portending greater morbidity than CTD without lung involvement ${ }^{1}$. While nearly all CTD may be associated with ILD, systemic sclerosis (SSc), the idiopathic inflammatory myopathies (IIM), and rheumatoid arthritis (RA) report the highest prevalences ${ }^{2-4}$. Radiologic patterns and clinical manifestations vary according to subtype while pulmonary function is frequently characterized by restrictive ventilatory defect and reduced diffusing capacity ${ }^{5}$. Therapy for the majority of CTD-ILD often involves an extension of medications already aimed at the underlying CTD, typically consisting of corticosteroids and steroid-sparing agents like cyclophosphamide (CYC), azathioprine (AZA), and mycophenolate mofetil (MMF) ${ }^{3}$. Except for scleroderma-ILD, management of CTD-ILD remains experiential or empiric due to lack of robust randomized controlled trials (RCT). Heterogeneity of disease subtypes, unclear and variable outcome measures, and relatively better survival compared to other progressive ILD like idiopathic pulmonary fibrosis (IPF) make large controlled studies difficult, requiring expansive RCTs with longer durations to differentiate functional or survival outcomes. Pulmonary function endpoints are often followed as reasonable markers of treatment effect.

Rituximab (RTX), a B-cell depleting chimeric monoclonal antibody against human CD20, is currently approved for the treatment of lymphoma and RA. With prior evidence suggesting aberrations in lymphocyte function may be involved in the development and evolution of CTD ${ }^{6}$, its use for the treatment of other CTD subtypes has gained recent interest. An initial report in 2008 involving patients with SSc-ILD ${ }^{7}$ supported its particular role in CTD with associated ILD, particularly those with clinically severe or progressive lung disease unresponsive to conventional immunosuppression ${ }^{8}$. Multiple case reports, case series, and one clinical trial have reported on the positive effects of rituximab in CTD-ILD though the extent of its effect on measured pulmonary function has not been summatively reported. This systematic review and meta-analysis summarizes the pooled effect size of RTX on lung function (percent predicted forced vital capacity (FVC\%) and diffusion capacity for carbon monoxide (DLCO\%)) and describes reported safety outcomes in the treatment of CTD-ILD.

\section{Materials And Methods}

The current systematic review and meta-analysis was conducted and reported according to the Preferred Reporting Items for Systematic reviews and MetaAnalyses (PRISMA) ${ }^{9}$ guideline and statement. The Cochrane Handbook for Systematic Reviews of Interventions ${ }^{10}$ provided the methodology for metaanalysis, and specific scoring of the included citations. The protocol was registered with ResearchRegistry (www.researchregistry.com; identifier reviewregistry1182).

\section{Literature Search and Study Selection}

PubMed, Cochrane Library, and Embase databases were searched for original full articles published in English from their inception to March 20, 2021. Search terms, combinations, and results are presented in e-Table 1. Studies were selected from case series reporting five or more cases, case-control, retrospective or prospective cohorts, and randomized or non-randomized controlled trials. Only adults (18 to 80 years of age) with a diagnosis of CTD-ILD were included. In terms of intervention, RTX was used individually or in combination with other immunosuppressive agents for at least six months or more (one cycle). Two reviewers ( $Y Z$ and $Y G)$ assessed the titles and abstracts of all search results with pre-specified inclusion and exclusion criteria. If the abstract of an article suggested relevance, the article was retrieved and independently assessed by the same reviewers for inclusion in either the descriptive review or metaanalysis of pulmonary function outcomes.

\section{Risk of Bias Assessment and Overall Quality of Evidence}

Risk of bias was assessed according to study type by the following: Cochrane collaboration tool for bias assessment in randomized controlled trials; Joanna Briggs Institute (JBI) critical appraisal checklist for quasi-experimental studies for nonrandomized observational studies; JBI critical appraisal checklist for conhort studies and the. IRI critical annraisal checklist for case series ${ }^{10,11}$. Publication bias was assessed by funnel plot and Egger test. Loading [MathJax]/jax/output/CommonHTML/jax.js 


\section{Data Extraction}

Pre-specified study data included design, duration of follow-up, setting, and performance dates. Participant data included number, mean age and age range, sex, and CTD-ILD subtype. Intervention data included RTX dose and number and concomitant immunosuppression. Adverse events or complications attributed to RTX were also collated and categorized. Disagreements regarding study inclusion were resolved by consensus between study reviewers (YZ and YG).

\section{Endpoints}

Primary meta-analysis outcomes were mean differences (MD) in percent predicted pre- and post-treatment reported forced vital capacity (FVC\%) and diffusion capacity for carbon monoxide (DLCO\%). Included articles for meta-analysis required reporting of specific pre- and post-treatment lung function findings or the mean changes in FVC\% or DLCO\% from baseline and their calculated standard deviations. Post-treatment FVC\% and DLCO\% were defined as obtained six months or greater from the first dose of RTX. All RTX dosages and infusion regimens were included, with all patients treated for at least one course of treatment (6 months). Drug-related adverse events from all studies were reviewed.

\section{Data Analysis}

Meta-analysis was performed using Comprehensive Meta-Analysis software version 3.3.070 (Biostat Inc, Englewood, NJ, USA). Descriptive analysis was conducted separately for non-combined studies $(n=6)$. Mean and standard deviation (SD) for changes in FVC\% and DLCO\% were calculated using the following equations from the Cochrane Handbook for Systematic Reviews of Interventions ${ }^{10}$ :

Mean change from baseline $=$ Mean $_{\text {post-treatment }}-$ Mean $_{\text {pre-treatment }}$

$$
\mathrm{SD}_{\text {change }}=\sqrt{\mathrm{SD}_{\text {baseline }}^{2}+\mathrm{SD}_{\text {final }}^{2}-\left(2 \times \mathrm{r} \times \mathrm{SD}_{\text {baseline }} \times \mathrm{SD}_{\text {final }}\right)}
$$

$\mathrm{R}$ in the equation above represents a correlation coefficient for which we imputed values of $0.4,0.6$, and 0.8 with sensitivity analysis for each. As the pooled MD results were similar for each value, we used a coefficient of 0.4 for $r$ in the meta-analysis. MD for FVC\% and DLCO\% were reported as mean changes from baseline with $95 \% \mathrm{Cl}$. A random-effects model with DerSimonian-Laird estimator of between-study variance was used to estimate final MD for each endpoint given baseline differences in study type and patient characteristics ${ }^{12}$. Magnitude of treatment effect may also vary according to sample size, disease subtype, concomitant treatment, or other unaccounted covariables, with a random effects model assuming effect size may be similar but not identical across all included studies with the intent of reporting the pooled true effects. The $R$ statistic was used to describe heterogeneity among the studies $(R>50 \%$ or $P$ value $<0.10$ for high heterogeneity). Meta-analysis data are presented as summary Forest plots for each PFT endpoint.

\section{Results}

\section{Study Selection and Characteristics}

A total of 3806 individual citations were found and screened, resulting in the inclusion of 20 studies for systematic review, 14 of which were included specifically in the quantitative meta-analysis of treatment effect size on lung function ${ }^{13-32}{ }^{2}$. Study selection is presented in Fig. 1 . Study exclusion on initial screening included non-English language, reporting of non-functional outcomes, reviews, editorials or commentary, incomplete manuscripts, lay press, and case reports with less than five cases. Tables 1 and 2 summarize study characteristics included in the meta-analysis $(n=14)$ and descriptive review $(n=6)$. Sample sizes ranged from seven to 56 , totaling 411 patients. Study subtypes included case series $(n=13)$, retrospective cohorts $(n=5)$, one non-randomized trial, and one RCT. Six studies reported the combined outcomes of several CTD-ILD; five for SSC-ILD and antisynthetase syndrome-ILD (ASS-ILD); three for RAILD, and one for primary Sjögren's-related-ILD (pSS). In most studies, RTX was administered as two $1000 \mathrm{mg}$ infusions two weeks apart, or $375 \mathrm{mg} / \mathrm{m} 2 \mathrm{weekly}$ for four weeks. Each cycle could be repeated at six-month intervals with all included studies reporting on the outcomes of at least one treatment cycle. Steroid-sparing immunosuppressant and other therapies included AZA, MMF, CYC, methotrexate (MTX) and intravenous immunoglobulin (IVIG). Pulmonary function outcomes were measured at baseline and after at least a first RTX treatment period (six months) up to one year. 
Table 1

) Characteristics of studies included in the meta-analysis ( $n=14$ studies)

\begin{tabular}{|c|c|c|c|c|c|c|c|c|c|}
\hline $\begin{array}{l}\text { Author \& } \\
\text { year }\end{array}$ & $\begin{array}{l}\text { CTD-ILD } \\
\text { subtype }\end{array}$ & Study design & $\mathbf{N}$ & RTX Dose & Duration & $\begin{array}{l}\text { Concurrent } \\
\text { treatment }\end{array}$ & Outcomes & $\begin{array}{l}\text { Duration } \\
\text { of follow- } \\
\text { up }\end{array}$ & $\begin{array}{l}\text { Adverse events } \\
\text { with RTX }\end{array}$ \\
\hline $\begin{array}{l}\text { Daoussis } \\
\text { et al. } \\
2012\end{array}$ & SSc-ILD & Case Series & 8 & $\begin{array}{l}\text { One cycle: IV, } \\
375 \mathrm{mg} / \mathrm{m}^{2} \text {, } \\
\text { once } \\
\text { weekly*4 } \\
\text { weeks, every } \\
6 \text { months }\end{array}$ & 4 cycles & None & $\begin{array}{l}\text { FVC; } \\
\text { DLCO }\end{array}$ & 2 years & $\begin{array}{l}2 \text { respiratory } \\
\text { infections } \\
\text { requiring } \\
\text { hospitalization, } \\
1 \text { with } \\
\text { associated } \\
\text { leukopenia, } 1 \\
\text { infusion } \\
\text { reaction }\end{array}$ \\
\hline $\begin{array}{l}\text { Keir et al. } \\
2012\end{array}$ & CTD-ILD & Case Series & 6 & $\begin{array}{l}\text { One cycle: } 5 \text { - } \\
\text { IV, } 1,000 \mathrm{mg} \\
\text { administered } \\
\text { on day } 0 \text { and } \\
\text { day } 14 \\
1 \text { patient: } \\
375 \mathrm{mg} / \mathrm{m}^{2} \text {, } \\
\text { once } \\
\text { weekly* } 4 \\
\text { weeks }\end{array}$ & 1 cycle & None & $\begin{array}{l}\text { FVC; } \\
\text { DLCO }\end{array}$ & $\begin{array}{l}9-12 \\
\text { months }\end{array}$ & None \\
\hline $\begin{array}{l}\text { Fitzgerald } \\
\text { et al. } \\
2015\end{array}$ & CTD-ILD & Case Series & 10 & $\begin{array}{l}\text { a. } 1-1000 \mathrm{mg} \\
\text { monthly } \\
\text { b. 2-IV, } \\
375 \mathrm{mg} / \mathrm{m}^{2} \text {, } \\
\text { monthly } \\
\text { c. 7-IV, } 1,000 \\
\mathrm{mg} \\
\text { administered } \\
\text { on day } 0 \text { and } \\
\text { day } 14\end{array}$ & $\begin{array}{l}\mathrm{a}, \mathrm{b} * 4 \\
\text { months; } \\
\mathrm{c}^{\star} 6 \text { months }\end{array}$ & $C Y C * 3$ & $\begin{array}{l}\text { FVC; } \\
\text { DLCO }\end{array}$ & $\begin{array}{l}3-27 \\
\text { months }\end{array}$ & None \\
\hline $\begin{array}{l}\text { Chen et } \\
\text { al. } 2016\end{array}$ & $\begin{array}{l}\text { Sjögren's } \\
\text { syndrome- } \\
\text { ILD }\end{array}$ & Case Series & 10 & $\begin{array}{l}\text { One cycle: IV, } \\
1,000 \mathrm{mg} \\
\text { administered } \\
\text { on day } 0 \text { and } \\
\text { day } 14\end{array}$ & $\begin{array}{l}\text { Repeated the } \\
\text { same } \\
\text { protocol every } \\
\text { half a year } \\
\text { depending on } \\
\text { Individual } \\
\text { response }\end{array}$ & Hydroxychloroquine & $\begin{array}{l}\text { FVC; } \\
\text { DLCO }\end{array}$ & 6 months & None \\
\hline $\begin{array}{l}\text { Lepri et } \\
\text { al. } 2016\end{array}$ & CTD-ILD & Case Series & 21 & $\begin{array}{l}\text { Cumulative } \\
\text { mean dose: } \\
\text { SYN: } 1.91 \mathrm{~g} ; \\
\text { SSc: } 1.75 \mathrm{~g} ; \\
\text { MCTD: } 1.4 \mathrm{~g}\end{array}$ & 2 years & $\begin{array}{l}\text { ASS: Azathioprine* } \\
8, \text { MTX}^{\star} 1 \text {, IVIG* } 1 \text {, } \\
\text { cyclosporine* } 1 \text {, } \\
\text { CYC*3; } \\
\text { SSc: MTX*9, MMF*1 } \\
\text { MCTD: MMF, CYC, } \\
\text { MTX }\end{array}$ & $\begin{array}{l}\text { FVC; } \\
\text { DLCO }\end{array}$ & 2 years & $\begin{array}{l}1 \text { arrhythmia; } 3 \\
\text { fatigue; } \\
8 \text { infections ( } 2 \\
\text { serious with } \\
\text { hospitalization) }\end{array}$ \\
\hline $\begin{array}{l}\text { Sharp et } \\
\text { al. } 2016\end{array}$ & CTD-ILD & Case Series & 24 & $\begin{array}{l}\text { One cycle: IV, } \\
1,000 \mathrm{mg} \\
\text { administered } \\
\text { on day } 0 \text { and } \\
\text { day } 14\end{array}$ & $1-2$ cycles & $\begin{array}{l}\text { Oral } \\
\text { immunosuppression }\end{array}$ & $\begin{array}{l}\text { FVC; } \\
\text { DLCO }\end{array}$ & $\begin{array}{l}6-12 \\
\text { months }\end{array}$ & None \\
\hline $\begin{array}{l}\text { Daoussis } \\
\text { et al. } \\
2017\end{array}$ & SSc-ILD & $\begin{array}{l}\text { Cohort } \\
\text { (prospective) }\end{array}$ & 33 & 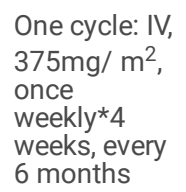 & $\geq 2$ cycles & $\begin{array}{l}\text { MTX*2; } \\
\text { Hydroxychloro- } \\
\text { quine*1; } \\
\text { MMF*10 }\end{array}$ & $\begin{array}{l}\text { FVC; } \\
\text { DLCO }\end{array}$ & 2 years & $\begin{array}{l}2 \text { infusion } \\
\text { reactions }\end{array}$ \\
\hline $\begin{array}{l}\text { Md Yusof } \\
\text { et al. } \\
2017\end{array}$ & RA-ILD & $\begin{array}{l}\text { Cohort } \\
\text { (retrospective) }\end{array}$ & 56 & $\begin{array}{l}\text { One cycle: } \\
\text { IV, } 1,000 \mathrm{mg} \\
\text { administered } \\
\text { on day } 1 \text { and } \\
\text { day } 14\end{array}$ & $\geq 1$ cycle & $\mathrm{CYC}$ & $\begin{array}{l}\text { FVC; } \\
\text { DLCO }\end{array}$ & $\begin{array}{l}6- \\
12 \text { months }\end{array}$ & $\begin{array}{l}12 \text { chest } \\
\text { infections } \\
\text { (none } \\
\text { hospitalized) }\end{array}$ \\
\hline
\end{tabular}




\begin{tabular}{|c|c|c|c|c|c|c|c|c|c|}
\hline $\begin{array}{l}\text { Author \& } \\
\text { year }\end{array}$ & $\begin{array}{l}\text { CTD-ILD } \\
\text { subtype }\end{array}$ & Study design & $\mathbf{N}$ & RTX Dose & Duration & $\begin{array}{l}\text { Concurrent } \\
\text { treatment }\end{array}$ & Outcomes & $\begin{array}{l}\text { Duration } \\
\text { of follow- } \\
\text { up }\end{array}$ & $\begin{array}{l}\text { Adverse events } \\
\text { with RTX }\end{array}$ \\
\hline $\begin{array}{l}\text { Sari et al. } \\
2017\end{array}$ & SSc-ILD & Case Series & 14 & $\begin{array}{l}\text { One cycle: IV, } \\
1,000 \text { or } \\
500 \mathrm{mg}, 2 \\
\text { infusions } \\
\text { biweekly }\end{array}$ & $\begin{array}{l}4 \text { received } 1 \\
\text { cycle; } \\
2 \text { received } 2 \\
\text { cycles; } \\
2 \text { received } 3 \\
\text { cycles; } \\
4 \text { received } 4 \\
\text { cycles; } \\
2 \text { received } 5 \\
\text { cycles }\end{array}$ & None & FVC & $\begin{array}{l}15 \\
\text { months }\end{array}$ & None \\
\hline $\begin{array}{l}\text { Doyle et } \\
\text { al. } 2018\end{array}$ & ASS-ILD & Case Series & 12 & $\begin{array}{l}\text { Not } \\
\text { mentioned }\end{array}$ & $\begin{array}{l}\text { Mean time to } \\
\text { initiation of } \\
\text { RTX after ILD } \\
\text { identification: } \\
4.4 \text { years }\end{array}$ & $\begin{array}{l}\text { Azathioprine, MMF, } \\
\text { CYC, IVIG }\end{array}$ & $\begin{array}{l}\text { FVC; } \\
\text { DLCO }\end{array}$ & 2 years & $\begin{array}{l}1 \text { anaphylaxis } \\
\text { and } 2 \text { serious } \\
\text { gastrointestinal } \\
\text { complications } \\
\text { requiring } \\
\text { surgery (not } \\
\text { described), but } \\
\text { later resumed } \\
\text { RTX }\end{array}$ \\
\hline $\begin{array}{l}\text { Sircar et } \\
\text { al. } 2018\end{array}$ & SSc-ILD & RCT & 30 & $\begin{array}{l}\text { One cycle: IV, } \\
1,000 \mathrm{mg} \\
\text { administered } \\
\text { on day } 0 \text { and } \\
\text { day } 15, \text { every } \\
6 \text { months }\end{array}$ & 2 cycles & None & FVC & 6 months & $\begin{array}{l}1 \text { severe } \\
\text { pulmonary } \\
\text { arterial } \\
\text { hypertension, } 3 \\
\text { infusion } \\
\text { reactions }\end{array}$ \\
\hline $\begin{array}{l}\text { Duarte et } \\
\text { al. } 2019\end{array}$ & CTD-ILD & Case Series & 49 & $\begin{array}{l}\text { One cycle: IV, } \\
1,000 \text { mg, } 2 \\
\text { infusions } \\
\text { biweekly }\end{array}$ & $\begin{array}{l}\text { Median } \\
\text { number of } \\
\text { cycles was } 2\end{array}$ & None & $\begin{array}{l}\text { FVC; } \\
\text { DLCO }\end{array}$ & 1 year & None \\
\hline $\begin{array}{l}\text { Ebata et } \\
\text { al. } 2019\end{array}$ & SSc-ILD & $\begin{array}{l}\text { non- } \\
\text { randomized } \\
\text { study } \\
\text { (retrospective) }\end{array}$ & 9 & $\begin{array}{l}\text { One cycle: IV, } \\
375 \mathrm{mg} / \mathrm{m}^{2} \text {, } \\
\text { once } \\
\text { weekly*4 } \\
\text { weeks }\end{array}$ & $\begin{array}{l}1 \text { up to } 3 \\
\text { cycles }\end{array}$ & $\begin{array}{l}\text { Maintenance } \\
\text { therapy with } \\
\text { immunosuppressant } \\
\text { agents }\end{array}$ & $\begin{array}{l}\text { FVC; } \\
\text { DLCO }\end{array}$ & 2 years & None \\
\hline $\begin{array}{l}\text { Fui et al. } \\
2019\end{array}$ & RA-ILD & $\begin{array}{l}\text { Cohort } \\
\text { (retrospective) }\end{array}$ & 14 & $\begin{array}{l}\text { One cycle: IV, } \\
1,000 \mathrm{mg} \\
\text { administered } \\
\text { on day } 0 \text { and } \\
\text { day } 14\end{array}$ & $\begin{array}{l}\text { Treated for } \\
\text { more than } 1 \\
\text { year }\end{array}$ & None & $\begin{array}{l}\text { FVC; } \\
\text { DLCO }\end{array}$ & 1 year & $\begin{array}{l}\text { discontinued in } \\
2 \text { patients with } \\
\text { refractory } \\
\text { severe arthritis }\end{array}$ \\
\hline
\end{tabular}


Table 2

) Characteristics of studies included in the descriptive review ( $\mathrm{n}=6$ studies)

\begin{tabular}{|c|c|c|c|c|c|c|c|c|c|c|}
\hline $\begin{array}{l}\text { Study } \\
\text { name \& } \\
\text { year }\end{array}$ & $\begin{array}{l}\text { CTD- } \\
\text { ILD } \\
\text { Subtype }\end{array}$ & Type of study & $\mathbf{N}$ & RTX Dose & Duration & $\begin{array}{l}\text { Concurrent } \\
\text { Immunotherapy }\end{array}$ & Outcomes & $\begin{array}{l}\text { Clinical } \\
\text { Follow- } \\
\text { up }\end{array}$ & $\begin{array}{l}\text { Adverse } \\
\text { events with } \\
\text { RTX }\end{array}$ & $\begin{array}{l}\text { Primary } \\
\text { reason for } \\
\text { qualitative } \\
\text { review }\end{array}$ \\
\hline \multirow{5}{*}{$\begin{array}{l}\text { Sem et al. } \\
2009\end{array}$} & \multirow[t]{5}{*}{ ASS-ILD } & \multirow[t]{5}{*}{ Case Series } & \multirow[t]{5}{*}{11} & One cycle: & \multirow[t]{5}{*}{1 cycle } & \multirow[t]{5}{*}{ None } & FVC; & \multirow{5}{*}{$\begin{array}{l}6 \\
\text { months }\end{array}$} & \multirow{5}{*}{$\begin{array}{l}1 \text { infusion } \\
\text { reaction }\end{array}$} & \multirow{5}{*}{$\begin{array}{l}\text { Provided only } \\
\text { percentage } \\
\text { improvements }\end{array}$} \\
\hline & & & & $\begin{array}{l}\text { 2-IV, 375mg/ } \\
\mathrm{m}^{2} \text {, monthly; }\end{array}$ & & & \multirow[t]{4}{*}{ DLCO } & & & \\
\hline & & & & $\begin{array}{l}\text { 8-IV, 1,000 } \\
\text { mg } \\
\text { administered }\end{array}$ & & & & & & \\
\hline & & & & $\begin{array}{l}\text { on day } 0 \text { and } \\
\text { day } 14 ;\end{array}$ & & & & & & \\
\hline & & & & $\begin{array}{l}\text { 1-IV, } 700 \mathrm{mg} \\
\text { administered } \\
\text { on day } 0 \text { and } \\
\text { day } 14\end{array}$ & & & & & & \\
\hline \multirow{2}{*}{$\begin{array}{l}\text { Marie et } \\
\text { al. } 2012\end{array}$} & \multirow[t]{2}{*}{ ASS-ILD } & \multirow[t]{2}{*}{ Case Series } & \multirow[t]{2}{*}{7} & \multirow{2}{*}{$\begin{array}{l}\text { One cycle: IV, } \\
1,000 \mathrm{mg} \\
\text { administered } \\
\text { on day } 0 \text { and } \\
\text { day } 14\end{array}$} & \multirow{2}{*}{$\begin{array}{l}1 \text { cycle } \\
\text { and } \\
\text { another } \\
\text { IV } 1 \mathrm{~g} \\
\text { after } 6 \\
\text { months }\end{array}$} & \multirow[t]{2}{*}{ None } & FVC; & \multirow[t]{2}{*}{1 year } & \multirow[t]{2}{*}{ None } & \multirow{2}{*}{$\begin{array}{l}\text { No standard } \\
\text { deviation data } \\
\text { before and } \\
\text { after } \\
\text { treatment }\end{array}$} \\
\hline & & & & & & & DLCO & & & \\
\hline \multirow{2}{*}{$\begin{array}{l}\text { Allenbach } \\
\text { et al. } 2015\end{array}$} & \multirow[t]{2}{*}{ ASS-ILD } & \multirow[t]{2}{*}{ Case Series } & \multirow[t]{2}{*}{10} & \multirow{2}{*}{$\begin{array}{l}\text { One cycle: IV, } \\
1,000 \mathrm{mg} \\
\text { administered } \\
\text { on day } 0 \text { and } \\
\text { day } 14\end{array}$} & \multirow{2}{*}{$\begin{array}{l}1 \text { cycle } \\
\text { and } \\
\text { another } \\
\text { IV } 1 \mathrm{~g} \\
\text { after } 6 \\
\text { months }\end{array}$} & \multirow[t]{2}{*}{ IVIG } & FVC; & \multirow[t]{2}{*}{1 year } & \multirow{2}{*}{$\begin{array}{l}6 \text { infections } \\
\text { (not } \\
\text { hospitalized) }\end{array}$} & \multirow{2}{*}{$\begin{array}{l}\text { No specific } \\
\text { data on PFT } \\
\text { change }\end{array}$} \\
\hline & & & & & & & DLCO & & & \\
\hline \multirow{5}{*}{$\begin{array}{l}\text { Andersson } \\
\text { et al. } 2015\end{array}$} & \multirow[t]{5}{*}{ ASS-ILD } & \multirow[t]{5}{*}{ Case Series } & \multirow[t]{5}{*}{24} & $\begin{array}{l}\text { 2-IV, } \\
275 \mathrm{ma} / \mathrm{m}^{2}\end{array}$ & $\begin{array}{l}\text { Median } \\
\text { number }\end{array}$ & AZA, CYC, MMF & FVC; & $\begin{array}{l}10-60 \\
\text { months }\end{array}$ & $\begin{array}{l}6 \text { infections } \\
\text { (not }\end{array}$ & $\begin{array}{l}\text { No standard } \\
\text { deviation data }\end{array}$ \\
\hline & & & & monthly; & & & DLCO & & & \\
\hline & & & & $\begin{array}{l}21-I V, 1,000 \\
\text { mg } \\
\text { administered }\end{array}$ & was 2.7 & & & & purpuric rash & treatment \\
\hline & & & & $\begin{array}{l}\text { on day } 0 \text { and } \\
\text { day } 14 ;\end{array}$ & & & & & & \\
\hline & & & & $\begin{array}{l}\text { 1- reduced } \\
\text { dose } \\
\text { because of } \\
\text { perceived } \\
\text { infection risk }\end{array}$ & & & & & & \\
\hline $\begin{array}{l}\text { Chartrand } \\
\text { et al. } 2016\end{array}$ & $\begin{array}{l}\text { CTD- } \\
\text { ILD }\end{array}$ & $\begin{array}{l}\text { Cohort } \\
\text { (retrospective) }\end{array}$ & 24 & One cycle: & $\begin{array}{l}14 \geq 1 \\
\text { cycles }\end{array}$ & MMF, CYC & FVC & $\begin{array}{l}\geq 2 \\
\text { years }\end{array}$ & $\begin{array}{l}1 \text { infusion } \\
\text { reaction }\end{array}$ & $\begin{array}{l}\text { Provided FVC } \\
\text { curves but no }\end{array}$ \\
\hline & & & & $\begin{array}{l}22-\mathrm{IV}, 1,000 \\
\text { mg } \\
\text { administered } \\
\text { on day } 0 \text { and } \\
\text { day } 14 ;\end{array}$ & & & & & & $\begin{array}{l}\text { raw data } \\
\text { values }\end{array}$ \\
\hline & & & & $\begin{array}{l}\text { 2-IV, } 375 \mathrm{mg} / \\
\mathrm{m}^{2}, \text { once } \\
\text { weekly*4 } \\
\text { weeks }\end{array}$ & & & & & & \\
\hline $\begin{array}{l}\text { Vadillo et } \\
\text { al. } 2020\end{array}$ & RA-ILD & $\begin{array}{l}\text { Cohort } \\
\text { (prospective) }\end{array}$ & 31 & $\begin{array}{l}\text { Not } \\
\text { mentioned }\end{array}$ & $\begin{array}{l}\text { Median } \\
\text { number }\end{array}$ & None & FVC; & 6 years & $\begin{array}{l}1 \text { infection } \\
\text { and } 1\end{array}$ & $\begin{array}{l}\text { Provided only } \\
\text { mean }\end{array}$ \\
\hline & & & & specifically & $\begin{array}{l}\text { of } \\
\text { cycles } \\
\text { was } 3.4\end{array}$ & & DLCO & & pancytopenia & $\begin{array}{l}\text { difference } \\
\text { values } \\
\text { without } \\
\text { calculatable } \\
\text { SD }\end{array}$ \\
\hline
\end{tabular}

Effect size of RTX on FVC\% and DLCO\% Endpoints

A total of 296 CTD-ILD patients from 14 studies with available pre- and post-treatment FVC\% contributed to the quantitative meta-analysis $(R=0 \%$, $P=.94)$. There was an increase in FVC\% before and after RTX treatment with a MD of 4.57\% [95\% Cl, 2.63-6.51] (Fig. 2). Quantitative meta-analysis for DLCO\% included 246 patients from ten studies $(R=10 \%, P=.34)$. There was an increase in DLCO\% (MD 5.0\% [95\% Cl 2.71-7.29]) after RTX treatment (Fig. 3).

Safety Outcomes as reported for all studies 
Infusion related reactions, including fever, chills, and rigors were the most reported adverse effects along with non-serious infections. Fifty six of 411 treated patients suffered some type of adverse effect (13.6\%). As presented in Table 1, one study reported 12 non-serious chest infections ${ }^{14}$ while eight studies reported zero events. There were no reported deaths as a direct result of RTX treatment.

\section{Risk of Bias and Publication Bias Assessment}

Systematic biases were scored for included studies and presented in e-Table 2. A particular limitation for meta-analysis was the lack of RCT studies. As multiple reports with varied definitions of positive outcomes were available and our intent was to systematically review effect size, we included only those studies reporting specific baseline and post-treatment lung function. Many screened publications were also case reports with less than five patients, preemptively excluded due to smaller studies contributing greater bias. There did not appear to be publication bias for the two primary pulmonary function outcomes as represented by funnel plots (Figs. 4 and 5). The Egger's regression asymmetry test demonstrated $P$ values of 0.60 and 0.28 ( $P>0.05$ suggests no publication bias) for the outcomes of FVC\% and DLCO\%, respectively.

\section{Analysis of studies included in the descriptive review}

Six studies with various PFT outcomes but unreported specific pre and post treatment FVC\% and DLCO\% (with related standard deviation required for pooled analysis) that could not be combined were analyzed descriptively (Table 2). A cohort of 14 CTD-ILD patients who received more than one cycle of RTX found FVC\% trajectory increased in eight and declined in six ${ }^{23}$. Another RA-ILD study found RTX treatment appeared to lower the risk of respiratory impairment (defined as a decline $\geq 5 \%$ in the predicted FVC) compared to untreated historical controls (hazard ratio, 0.51 [ $95 \% \mathrm{Cl}, 0.31-0.85]$ ) ${ }^{18}$. Four case series reported RTX therapy in ASS-ILD. Andersson et al showed that median FVC\% and DLCO $\%$ increased by $24 \%$ and $17 \%$ respectively in 24 patients on RTX treatment for a median number of 2.7 cycles ${ }^{20}$. A case series of seven patients found that after one year of RTX treatment, median FVC\% increased from $66 \%$ [range: $35-76$ ] to $74 \%$ [range: $57-108$ ] $(P=0.04)$; and median DLCO\% increased from $39 \%$ [range: $20-57$ ] to $59 \%$ [range: $49-72$ ] $(P=0.001){ }^{27}$. Neither study was included in the quantitative meta-analysis due to the absence of reported and non-calculatable standard deviations for each PFT outcome. Allenbach et al summarized the FVC findings of ten patients after 1.5 cycles of RTX, showing FVC improvement in four, stability in five, and worsening in one ${ }^{17}$. Lastly, a final study involving ASS-ILD found that after one cycle RTX, six of eleven patients showed $>10 \%$ improvement in FVC\% and 3 had $>15 \%$ improvement in DLCO 31 .

\section{Discussion}

To our knowledge this is the first systematic review and meta-analysis to assess RTX effect size on FVC\% (MD of 4.57\%) and DLCO\% (MD of 5.0\%) in patients with CTD-ILD, reporting a low but not insignificant level of drug-related adverse effects ( $13.6 \%$ of the pooled cohort). Over 240 pooled patient observations were included for each functional endpoint suggesting RTX may modestly improve or stabilize lung function as an adjunct to traditional immunosuppression.

While the combined effect size on PFT outcomes for CTD-ILD was reported here, it is worth reviewing the individual characteristics and responses to RTX in reported specific diseases. SSc has the highest mortality associated with ILD ${ }^{33}$ along with the highest ILD prevalence ${ }^{34}$. Incidentally, studies involving SScILD patients were also the largest represented subtype in our meta-analysis. FVC\% appeared to improve after RTX therapy in the combined meta-analysis ${ }^{13}$, $15,21,22,30$ inclusive of the only RCT in our systematic review ${ }^{19}$. Divergent findings though were reported in 23 patients of a subgroup in the study by Lepri et al ${ }^{15}$. Similarly, DLCO in SSc-ILD appeared to stabilize or improve with RTX treatment. The second largest group of represented CTD-ILD in our meta-analysis was ASS-ILD, whose disease-defining manifestations often include inflammatory myopathy, ILD, arthritis, and various hand manifestations ${ }^{35,36}$. ILD prevalence ranges from 67 to $100 \%$ based on antibody type and the diagnostic criteria used ${ }^{37,38}$. Our meta-analysis and descriptive review included five studies demonstrating FVC improvement or stability with RTX 17, 20,26, 27, 31. ILD is also an important comorbidity of RA often associated with similar outcomes to IPF, prompting novel approaches to treatment to improve or extend survival ${ }^{39}$. RTX has already been approved for the treatment of joint symptoms while there is less data on the treatment of related ILD. RTX demonstrated stabilization and in some cases, improvement of ILD in patients with $\mathrm{RA}^{40}$. All included studies in our meta-analysis suggested stabilization or improvement of FVC and DLCO ${ }^{14,18,28}$. ILD associated with primary Sjögren's syndrome (pSS) occurs less commonly compared to other CTD though contributes to significant morbidity and mortality 41,42 . RTX may be a promising treatment in this setting given the suggested role of B cell hyperactivity in the immunopathogenesis of pSS ${ }^{43}$. The study by Chen et al in included in this meta-analysis suggests RTX may stabilize pulmonary function in patients with pSS ${ }^{29}$.

Data for treatment of the other CTD-ILD with RTX remains limited. ILD prevalence in the idiopathic inflammatory myopathies (IIMs) is about $30-40 \%$, and contributes to an estimated mortality of $40 \%{ }^{44}$. A recent systematic review suggested immunosuppressive therapies were associated with significant functional improvement for most patients with IIMs and chronic ILD, though the mortality of rapidly progressive disease remains high ${ }^{45}$. A case report of four patients on RTX therapy for rapidly progressive lung disease related to anti-MDA5 antibody-positive amyopathic dermatomyositis showed clinically significant improvement in lung function, though post-treatment infection risk was increased ${ }^{46}$. ILD is less common in systemic lupus erythematosus (SLE). A large multicenter observational cohort of 147 patients suggested RTX may be a possible maintenance option ${ }^{47}$, though little data was provided regarding response of ILD findings to directed treatment. In contrast, there are reports of rituximab-induced interstitial pneumonitis seen in SLE patients ${ }^{48}$.

Pooled analysis across a spectrum of CTD-ILD suggested a modest 4-5\% increase in both FVC\% and DLCO\% after treatment with RTX compared to stabilization or slowing of prior decline. Similar effect in improved PFT findings were seen in prior observational and RCTs assessing CYC and MMF in patients with scleroderma-ILD ${ }^{49-52}$, as well as azathioprine in one series of CTD patients with fibrotic ILD ${ }^{53}$. Specific effect sizes ranged from $1.5-15 \%$ in terms of FVC\% change. In the majority of included studies for this meta-analysis, patients were considered non-responsive or refractory to typical

\footnotetext{
Loading [MathJax]/jax/output/CommonHTML/jax.js role for the targeting of other immune-mediated or inflammatory processes for RTX. Whether an increase in
} 
FVC\% or DLCO\% of 4 to $5 \%$ compared to pre-treatment baseline is clinically relevant (in terms of symptomatic or radiologic improvement), or is sustained with subsequent treatment, was not accounted for in this meta-analysis but remain important caveats to real-world disease management and assessment of risk/benefit ratios, particularly regarding the more prolonged and less immediately reversible immunosuppression associated with RTX. As precedence, one study reported the direct effects of immunosuppressant treatment (not RTX) on patient-reported outcomes and health-related quality of life in sclerodermaILD patients, noting improvements in PRO scores meeting minimal clinically important differences, but little correlation with baseline or subsequent FVC change ${ }^{54}$.

Indeed, cost and concern for serious adverse effects may limit immediate or first-line use of RTX in the treatment of CTD-ILD. Our systematic review suggests RTX was overall well-tolerated and safe in the majority of treated CTD-ILD patients ${ }^{55}$, including those on long-term therapy ${ }^{56}$. RTX-associated interstitial lung disease (RTX-ILD) or lung injury may be particularly concerning in those with already present lung disease. However, RTX-related lung injury was previously reported more commonly in combination with other chemotherapeutic agents for the treatment of lymphoma, which may confound accurate assessments of causation ${ }^{57}$. No direct RTX-related ILD or lung injury was reported in our review, highlighted by only a few serious adverse events due to infection with no therapy-related deaths.

There are several limitations to our systematic review and meta-analysis. First, variation in disease subtype and patient characteristics likely increased pooled heterogeneity and limits a true assessment of treatment effect size. We accounted for this with use of a random effects model and estimated the degree of heterogeneity for each endpoint, though still found $P$ for example in the quantitative meta-analysis of FVC $(R=0 \%)$ was low and suggestive of little heterogeneity. It is known though that $R$ does not necessarily describe how much an effect size varies but more what proportion of the observed variance would remain if all sampling error could be eliminated. When $R$ is near zero dispersion in a forest plot may be minimal but does not suggest the absence of any heterogeneity, particularly when sample sizes in included studies were small with wider standard variations ${ }^{58}$. Additional limitations to our meta-analysis include the inability to account for duration of drug exposure, variation in timing of PFT follow-up, and the balance of CTD-ILD subtypes, of which pooled analyses may be weighed by one disease type over another. As presented in Table 1, patients treated with RTX in were also often treated first or concomitantly with other immunosuppressive agents. CYC has previously demonstrated short-term improvement in FVC in SSC-ILD patients, though with a higher incidence of adverse effects ${ }^{49,59}$. AZA as maintenance therapy after six months of CYC did not demonstrate significant FVC improvement in this same disease subtype ${ }^{60}$. MMF is thought to be safer and equally effective in the management of CTD-ILD when compared to CYC and AZA ${ }^{49}, 53$. We could not account for the role of concomitant therapy which may have also contributed to measured effect sizes.

\section{Conclusion}

The present systematic review and meta-analysis suggests a modest stabilization or improvement in pulmonary function (FVC\% and DLCO\%) in CTD-ILD patients treated with RTX. There also appears to be a relatively safe adverse effects profile alone or in combination with other immunosuppressant agents. However, the lack of RCTs and other controlled quantitative studies along with heterogeneity of underlying diseases when data is pooled may pose important limitations for the confident use of RTX in real-world practice, with treatment initiation considered on a case-by-case basis.

\section{Abbreviations}

\section{ASS}

antisynthetase syndrome

AZA

azathioprine

$\mathrm{Cl}$

confidence interval

CTD

connective-tissue disease

CTD-ILD

connective-tissue disease-related interstitial lung disease

CYC

cyclophosphamide

DLCO\%

percent predicted diffusion capacity for carbon monoxide

FVC\%

percent predicted forced vital capacity

IIM

idiopathic interstitial pneumonia

ILD

interstitial lung disease

JBI

Joanna Briggs Institute

MMF

mvconhenolate mofetil

Loading [MathJax]/jax/output/CommonHTML/jax.js 
pulmonary function test

PRISMA

Preferred Reporting Items for Systematic reviews and Meta-Analyses

pSS

primary Sjögren's syndrome

RA

rheumatoid arthritis

RTX

rituximab

SSC

systemic sclerosis

SLE

systemic lupus erythematosus

WMD

weighted mean difference

\section{Declarations}

\section{Ethics approval and consent to participate}

Study was approved by Mayo Clinic Institutional Review Board prior to study initiation.

\section{Consent for publication}

None

\section{Availability of data and materials}

All data generated or analyzed during this study are included in this published article and its supplementary information files.

\section{Competing interests}

All authors report no related disclosures or conflicts of interest.

\section{Funding}

None

\section{Authors' contributions}

YZ and YG contributed equally to this work. $Y Z$ and $Y G$ performed the systematic review of databases, study data abstraction, and $Y Z, Y G, T P, W C, C T$, and $X Z$ completed the meta-analysis. All authors contributed to manuscript writing. YZ and TM are guarantors of this manuscript.

\section{Acknowledgments}

None

\section{References}

1. Fischer A, du Bois R. Interstitial lung disease in connective tissue disorders. The Lancet. 2012;380:689-98.

2. Castelino FV, Varga J. Interstitial lung disease in connective tissue diseases: evolving concepts of pathogenesis and management. Arthritis Res Ther. 2010;12:213.

3. Mathai SC, Danoff SK. Management of interstitial lung disease associated with connective tissue disease. BMJ. 2016;352:h6819.

4. Solomon JJ, Fischer A. Connective Tissue Disease-Associated Interstitial Lung Disease: A Focused Review. J Intensive Care Med. 2015;30:392-400.

5. Aduen JF, Zisman DA, Mobin SI, Venegas C, Alvarez F, Biewend M, Jolles HI, Keller CA. Retrospective study of pulmonary function tests in patients presenting with isolated reduction in single-breath diffusion capacity: implications for the diagnosis of combined obstructive and restrictive lung disease. Mayo Clin Proc. 2007; 82: 48-54.

6. Chizzolini C. T cells, B cells, and polarized immune response in the pathogenesis of fibrosis and systemic sclerosis. Curr Opin Rheumatol. 2008;20:70712.

7. McGonagle D, Tan AL, Madden J, Rawstron AC, Rehman A, Emery P, Thomas S. Successful treatment of resistant scleroderma-associated interstitial lung disease with rituximab. Rheumatology. 2008;47:552-3. 
8. Keir GJ, Maher TM, Ming D, Abdullah R, de Lauretis A, Wickremasinghe M, Nicholson AG, Hansell DM, Wells AU, Renzoni EA. Rituximab in severe, treatment-refractory interstitial lung disease. Respirology. 2014;19:353-9.

9. Liberati A, Altman DG, Tetzlaff J, Mulrow C, Gotzsche PC, loannidis JP, Clarke M, Devereaux PJ, Kleijnen J, Moher D. The PRISMA statement for reporting systematic reviews and meta-analyses of studies that evaluate health care interventions: explanation and elaboration. PLoS Med. 2009;6:e1000100.

10. Cumpston M, Li T, Page MJ, Chandler J, Welch VA, Higgins JP, Thomas J. Updated guidance for trusted systematic reviews: a new edition of the Cochrane Handbook for Systematic Reviews of Interventions. Cochrane Database Syst Rev. 2019;10:Ed000142.

11. Ma LL, Wang YY, Yang ZH, Huang D, Weng H, Zeng XT. Methodological quality (risk of bias) assessment tools for primary and secondary medical studies: what are they and which is better? Mil Med Res. 2020;7:7.

12. DerSimonian R, Laird N. Meta-analysis in clinical trials. Control Clin Trials. 1986;7:177-88.

13. Daoussis D, Liossis SC, Tsamandas AC, Kalogeropoulou C, Paliogianni F, Sirinian C, Yiannopoulos G, Andonopoulos AP. Effect of long-term treatment with rituximab on pulmonary function and skin fibrosis in patients with diffuse systemic sclerosis. Clin Exp Rheumatol. $2012 ; 30$.

14. Md Yusof MY, Kabia A, Darby M, Lettieri G, Beirne P, Vital EM, Dass S, Emery P. Effect of rituximab on the progression of rheumatoid arthritis-related interstitial lung disease: 10 years' experience at a single centre. Rheumatology. 2017;56:1348-57.

15. Lepri G, Avouac J, Airo P, Anguita Santos F, Bellando-Randone S, Blagojevic J, Garcia Hernandez F, Gonzalez Nieto JA, Guiducci S, Jordan S, Limaye V, Maurer B, Selva-O'Callaghan A, Riccieri V, Distler O, Matucci-Cerinic M, Allanore Y. Effects of rituximab in connective tissue disorders related interstitial lung disease. Clin Exp Rheumatol. 2016;34(Suppl 100):181-5.

16. Fitzgerald DB, Moloney F, Twomey M, O'Connell JO, Cronin O, Harty L, Harney S, Henry MT. Efficacy and Safety of Rituximab in Connective Tissue Disease related Interstitial Lung Disease. Sarcoidosis, vasculitis, and diffuse lung diseases. official journal of WASOG. 2015;32:215-21.

17. Allenbach Y, Guiguet M, Rigolet A, Marie I, Hachulla E, Drouot L, Jouen F, Jacquot S, Mariampillai K, Musset L, Grenier P, Devilliers H, Hij A, Boyer O, Herson S, Benveniste O. Efficacy of Rituximab in Refractory Inflammatory Myopathies Associated with Anti-Synthetase Auto-Antibodies: An Open-Label, Phase II Trial. PLoS One. 2015;10:e0133702.

18. Vadillo C, Nieto MA, Romero-Bueno F, Leon L, Sanchez-Pernaute O, Rodriguez-Nieto MJ, Freites D, Jover JA, Alvarez-Sala JL, Abasolo L. Efficacy of rituximab in slowing down progression of rheumatoid arthritis-related interstitial lung disease: data from the NEREA Registry. Rheumatology (Oxford). 2020.

19. Sircar G, Goswami RP, Sircar D, Ghosh A, Ghosh P. Intravenous cyclophosphamide vs rituximab for the treatment of early diffuse scleroderma lung disease: open label, randomized, controlled trial. Rheumatology. 2018;57:2106-13.

20. Andersson H, Sem M, Lund MB, Aalokken TM, Gunther A, Walle-Hansen R, Garen T, Molberg O. Long-term experience with rituximab in anti-synthetase syndrome-related interstitial lung disease. Rheumatology. 2015;54:1420-8.

21. Daoussis D, Melissaropoulos K, Sakellaropoulos G, Antonopoulos I, Markatseli TE, Simopoulou T, Georgiou P, Andonopoulos AP, Drosos AA, Sakkas L, Liossis SN. A multicenter, open-label, comparative study of B-cell depletion therapy with Rituximab for systemic sclerosis-associated interstitial lung disease. Semin Arthritis Rheum. 2017;46:625-31.

22. Sari A, Guven D, Armagan B, Erden A, Kalyoncu U, Karadag O, Apras Bilgen S, Ertenli I, Kiraz S, Akdogan A. Rituximab Experience in Patients With Longstanding Systemic Sclerosis-Associated Interstitial Lung Disease: A Series of 14 Patients. J Clin Rheumatol. 2017;23:411-5.

23. Chartrand S, Swigris JJ, Peykova L, Fischer A. Rituximab for the treatment of connective tissue disease-associated interstitial lung disease. Sarcoidosis, vasculitis, and diffuse lung diseases. official journal of WASOG. 2016;32:296-304.

24. Sharp C, McCabe M, Dodds N, Edey A, Mayers L, Adamali H, Millar AB, Gunawardena H. Rituximab in autoimmune connective tissue disease-associated interstitial lung disease. Rheumatology. 2016;55:1318-24.

25. Duarte AC, Cordeiro A, Fernandes BM, Bernardes M, Martins P, Cordeiro I, Santiago T, Seixas MI, Ribeiro AR, Santos MJ. Rituximab in connective tissue disease-associated interstitial lung disease. Clin Rheumatol. 2019;38:2001-9.

26. Doyle TJ, Dhillon N, Madan R, Cabral F, Fletcher EA, Koontz DC, Aggarwal R, Osorio JC, Rosas IO, Oddis CV, Dellaripa PF. Rituximab in the Treatment of Interstitial Lung Disease Associated with Antisynthetase Syndrome: A Multicenter Retrospective Case Review. J Rheumatol. 2018;45:841-50.

27. Marie I, Dominique S, Janvresse A, Levesque H, Menard JF. Rituximab therapy for refractory interstitial lung disease related to antisynthetase syndrome. Respir Med. 2012;106:581-7.

28. Fui A, Bergantini L, Selvi E, Mazzei MA, Bennett D, Pieroni MG, Rottoli P, Bargagli E. Rituximab Therapy in Interstitial Lung Disease associated with Rheumatoid Arthritis. Internal medicine journal. 2019.

29. Chen MH, Chen CK, Chou HP, Chen MH, Tsai CY, Chang DM. Rituximab therapy in primary Sjogren's syndrome with interstitial lung disease: a retrospective cohort study. Clin Exp Rheumatol. 2016;34:1077-84.

30. Ebata S, Yoshizaki A, Fukasawa T, Miura S, Takahashi T, Sumida H, Asano Y, Sato S. Rituximab therapy is more effective than cyclophosphamide therapy for Japanese patients with anti-topoisomerase I-positive systemic sclerosis-associated interstitial lung disease. J Dermatol. 2019;46:1006-13.

31. Sem M, Molberg O, Lund MB, Gran JT. Rituximab treatment of the anti-synthetase syndrome: a retrospective case series. Rheumatology. 2009;48:96871.

32. Keir GJ, Maher TM, Hansell DM, Denton CP, Ong VH, Singh S, Wells AU, Renzoni EA. Severe interstitial lung disease in connective tissue disease: rituximab as rescue therapy. Eur Respir J. 2012;40:641-8.

33. Denton CP, Khanna D. Systemic sclerosis. Lancet. 2017;390:1685-99.

Loading [MathJax]/jax/output/CommonHTML/jax.js 
34. Morales-Cárdenas A, Pérez-Madrid C, Arias L, Ojeda P, Mahecha MP, Rojas-Villarraga A, Carrillo-Bayona JA, Anaya JM. Pulmonary involvement in systemic sclerosis. Autoimmun Rev. 2016;15:1094-108.

35. Cavagna L, Nuño L, Scirè CA, Govoni M, Longo FJ, Franceschini F, Neri R, Castañeda S, Sifuentes Giraldo WA, Caporali R, lannone F, Fusaro E, Paolazzi G, Pellerito R, Schwarting A, Saketkoo LA, Ortego-Centeno N, Quartuccio L, Bartoloni E, Specker C, Murcia TP, La Corte R, Furini F, Foschi V, Corral JB, Airò P, Cavazzana I, Martínez-Barrio J, Hinojosa M, Giannini M, Barsotti S, Menke J, Triantafyllias K, Vitetta R, Russo A, Bajocchi G, Bravi E, Barausse G, Bortolotti R, Selmi C, Parisi S, Montecucco C, González-Gay MA. Clinical Spectrum Time Course in Anti Jo-1 Positive Antisynthetase Syndrome: Results From an International Retrospective Multicenter Study. Medicine (Baltimore). 2015; 94: e1144.

36. Mirrakhimov AE. Antisynthetase syndrome: a review of etiopathogenesis, diagnosis and management. Curr Med Chem. 2015;22:1963-75.

37. Hamaguchi Y, Fujimoto M, Matsushita T, Kaji K, Komura K, Hasegawa M, Kodera M, Muroi E, Fujikawa K, Seishima M, Yamada H, Yamada R, Sato S, Takehara K, Kuwana M. Common and distinct clinical features in adult patients with anti-aminoacyl-tRNA synthetase antibodies: heterogeneity within the syndrome. PLoS One. 2013;8:e60442.

38. Hervier B, Benveniste O. Clinical heterogeneity and outcomes of antisynthetase syndrome. Curr Rheumatol Rep. 2013;15:349.

39. Bongartz T, Nannini C, Medina-Velasquez YF, Achenbach SJ, Crowson CS, Ryu JH, Vassallo R, Gabriel SE, Matteson EL. Incidence and mortality of interstitial lung disease in rheumatoid arthritis: a population-based study. Arthritis Rheum. 2010;62:1583-91.

40. Carrasco Cubero C, Chamizo Carmona E, Vela Casasempere P. Systematic Review of the Impact of Drugs on Diffuse Interstitial Lung Disease Associated with Rheumatoid Arthritis. Reumatol Clin. 2020.

41. Roca F, Dominique S, Schmidt J, Smail A, Duhaut P, Levesque H, Marie I. Interstitial lung disease in primary Sjogren's syndrome. Autoimmun Rev. 2017;16:48-54.

42. Natalini JG, Johr C, Kreider M. Pulmonary Involvement in Sjögren Syndrome. Clin Chest Med. 2019;40:531-44.

43. Verstappen GM, van Nimwegen JF, Vissink A, Kroese FGM, Bootsma H. The value of rituximab treatment in primary Sjogren's syndrome. Clin Immunol. 2017;182:62-71.

44. Connors GR, Christopher-Stine L, Oddis CV, Danoff SK. Interstitial lung disease associated with the idiopathic inflammatory myopathies: what progress has been made in the past 35 years? Chest. 2010;138:1464-74.

45. Barba T, Fort R, Cottin V, Provencher S, Durieu I, Jardel S, Hot A, Reynaud Q, Lega JC. Treatment of idiopathic inflammatory myositis associated interstitial lung disease: A systematic review and meta-analysis. Autoimmun Rev. 2019;18:113-22.

46. So H, Wong VTL, Lao VWN, Pang HT, Yip RML. Rituximab for refractory rapidly progressive interstitial lung disease related to anti-MDA5 antibodypositive amyopathic dermatomyositis. Clin Rheumatol. 2018;37:1983-9.

47. Cassia MA, Alberici F, Jones RB, Smith RM, Casazza G, Urban ML, Emmi G, Moroni G, Sinico RA, Messa P, Hall F, Vaglio A, Gallieni M, Jayne DR. Rituximab as Maintenance Treatment for Systemic Lupus Erythematosus: A Multicenter Observational Study of 147 Patients. Arthritis Rheumatol. 2019;71:1670-80.

48. Kishi J, Nanki T, Watanabe K, Takamura A, Miyasaka N. A case of rituximab-induced interstitial pneumonitis observed in systemic lupus erythematosus. Rheumatology. 2009;48:447-8.

49. Tashkin DP, Elashoff R, Clements PJ, Goldin J, Roth MD, Furst DE, Arriola E, Silver R, Strange C, Bolster M, Seibold JR, Riley DJ, Hsu VM, Varga J, Schraufnagel DE, Theodore A, Simms R, Wise R, Wigley F, White B, Steen V, Read C, Mayes M, Parsley E, Mubarak K, Connolly MK, Golden J, Olman M, Fessler B, Rothfield N, Metersky M. Cyclophosphamide versus placebo in scleroderma lung disease. N Engl J Med. 2006;354:2655-66.

50. Tashkin DP, Roth MD, Clements PJ, Furst DE, Khanna D, Kleerup EC, Goldin J, Arriola E, Volkmann ER, Kafaja S, Silver R, Steen V, Strange C, Wise R, Wigley F, Mayes M, Riley DJ, Hussain S, Assassi S, Hsu VM, Patel B, Phillips K, Martinez F, Golden J, Connolly MK, Varga J, Dematte J, Hinchcliff ME, Fischer A, Swigris J, Meehan R, Theodore A, Simms R, Volkov S, Schraufnagel DE, Scholand MB, Frech T, Molitor JA, Highland K, Read CA, Fritzler MJ, Kim GHJ, Tseng CH, Elashoff RM. Sclerodema Lung Study III. Mycophenolate mofetil versus oral cyclophosphamide in scleroderma-related interstitial lung disease (SLS II): a randomised controlled, double-blind, parallel group trial. Lancet Respir Med. 2016;4:708-19.

51. Zamora AC, Wolters PJ, Collard HR, Connolly MK, Elicker BM, Webb WR, King TE Jr, Golden JA. Use of mycophenolate mofetil to treat sclerodermaassociated interstitial lung disease. Respir Med. 2008;102:150-5.

52. Volkmann ER, Tashkin DP, Li N, Roth MD, Khanna D, Hoffmann-Vold AM, Kim G, Goldin J, Clements PJ, Furst DE, Elashoff RM. Mycophenolate Mofetil Versus Placebo for Systemic Sclerosis-Related Interstitial Lung Disease: An Analysis of Scleroderma Lung Studies I and II. Arthritis Rheumatol. 2017;69:1451-60.

53. Oldham JM, Lee C, Valenzi E, Witt LJ, Adegunsoye A, Hsu S, Chen L, Montner S, Chung JH, Noth I, Vij R, Strek ME. Azathioprine response in patients with fibrotic connective tissue disease-associated interstitial lung disease. Respir Med. 2016;121:117-22.

54. Volkmann ER, Tashkin DP, LeClair H, Roth MD, Kim G, Goldin J, Clements PJ, Furst DE, Khanna D. Treatment With Mycophenolate and Cyclophosphamide Leads to Clinically Meaningful Improvements in Patient-Reported Outcomes in Scleroderma Lung Disease: Results of Scleroderma Lung Study II. ACR Open Rheumatol. 2020;2:362-70.

55. Kimby E. Tolerability and safety of rituximab (MabThera). Cancer Treat Rev. 2005;31:456-73.

56. Vikse J, Jonsdottir K, Kvaloy JT, Wildhagen K, Omdal R. Tolerability and safety of long-term rituximab treatment in systemic inflammatory and autoimmune diseases. Rheumatol Int. 2019;39:1083-90.

57. Hadjinicolaou AV, Nisar MK, Parfrey H, Chilvers ER, Ostör AJ. Non-infectious pulmonary toxicity of rituximab: a systematic review. Rheumatology. 2012;51:653-62.

Loading [MathJax]/jax/output/CommonHTML/jax.js 
58. Borenstein M, Higgins JP, Hedges LV, Rothstein HR. Basics of meta-analysis: I(2) is not an absolute measure of heterogeneity. Res Synth Methods. 2017;8:5-18.

59. Tashkin DP, Elashoff R, Clements PJ, Roth MD, Furst DE, Silver RM, Goldin J, Arriola E, Strange C, Bolster MB, Seibold JR, Riley DJ, Hsu VM, Varga J, Schraufnagel D, Theodore A, Simms R, Wise R, Wigley F, White B, Steen V, Read C, Mayes M, Parsley E, Mubarak K, Connolly MK, Golden J, Olman M, Fessler B, Rothfield N, Metersky M, Khanna D, Li N, Li G. Effects of 1-year treatment with cyclophosphamide on outcomes at 2 years in scleroderma lung disease. Am J Respir Crit Care Med. 2007;176:1026-34.

60. Hoyles RK, Ellis RW, Wellsbury J, Lees B, Newlands P, Goh NS, Roberts C, Desai S, Herrick AL, McHugh NJ, Foley NM, Pearson SB, Emery P, Veale DJ, Denton CP, Wells AU, Black CM, du Bois RM. A multicenter, prospective, randomized, double-blind, placebo-controlled trial of corticosteroids and intravenous cyclophosphamide followed by oral azathioprine for the treatment of pulmonary fibrosis in scleroderma. Arthritis Rheum. 2006;54:3962-70.

\section{Figures}

Figurel) PRISMA study selection.

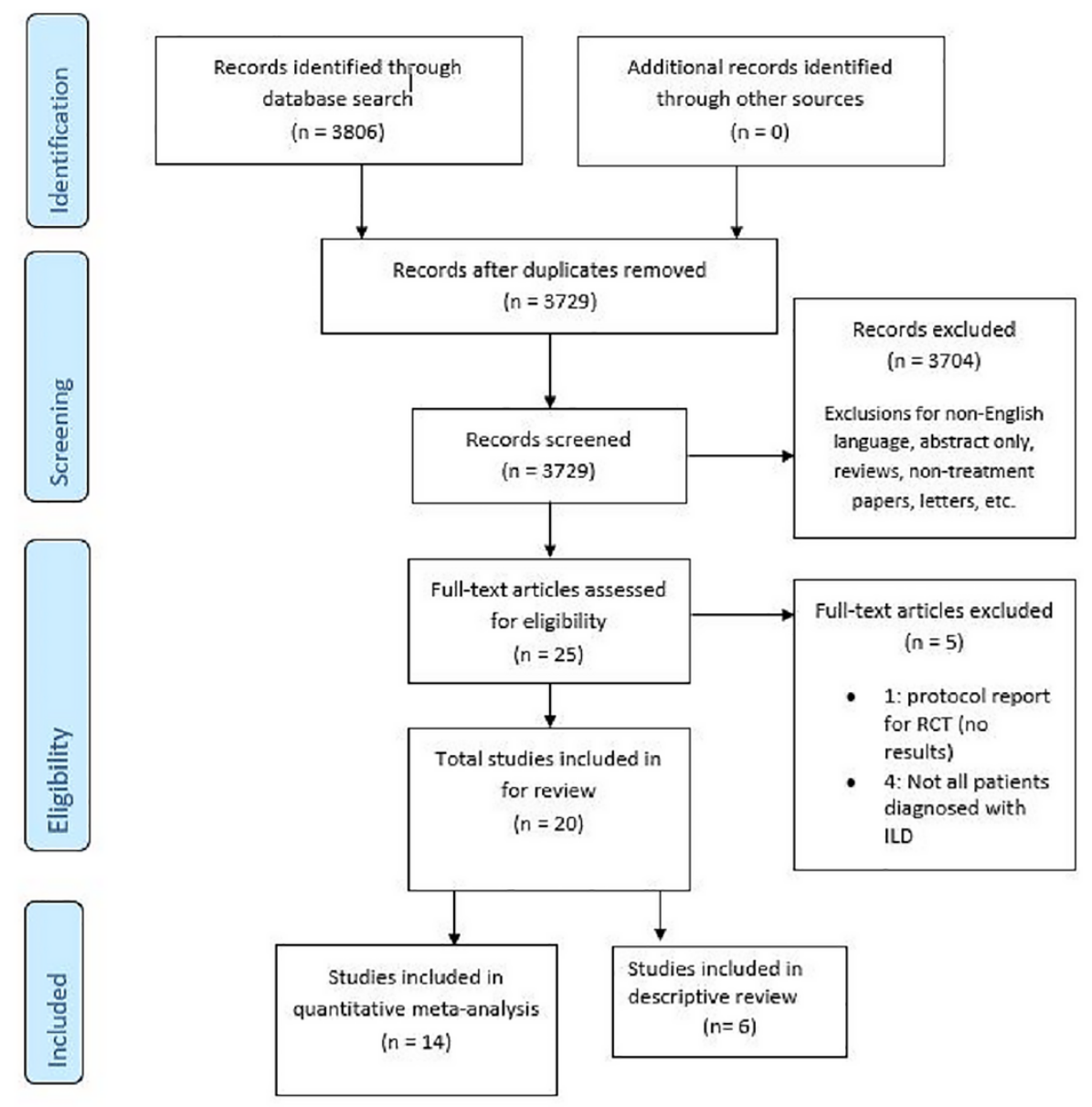

Figure 1

PRISMA study selection. 
Study name

Statistics for each study

\begin{tabular}{|c|c|c|c|c|c|c|c|c|}
\hline & $\begin{array}{c}\text { Difference } \\
\text { in means }\end{array}$ & $\begin{array}{l}\text { Standard } \\
\text { error }\end{array}$ & Variance & $\begin{array}{c}\text { Lower } \\
\text { limit }\end{array}$ & $\begin{array}{c}\text { Upper } \\
\text { limit }\end{array}$ & Z-Value & p-Value & Tota \\
\hline Deaussis eta 2012 & 9170 & 4.1६8 & 17.372 & 1.001 & 17.339 & 2200 & 0.028 & \\
\hline Keir eta 2012 & 2500 & $10 \% 6$ & 115.907 & -18601 & 23601 & 0232 & 0.816 & \\
\hline Fitzgeraddeta 2015 & 6460 & 10.527 & 110.818 & -14.173 & 27.003 & 0.614 & 0.59 & 10 \\
\hline Chen ed a 2016 & 1.700 & 8546 & 73.031 & -15.049 & 18.449 & 0.199 & 0.842 & 10 \\
\hline Leprieta (1) 2016 & -3500 & 4.879 & 23807 & -13053 & 6003 & -0.717 & 0.473 & \\
\hline Lepri eta (Z) 2016 & 10060 & 17.194 & 206647 & -23600 & 43750 & 0.584 & 0.569 & \\
\hline Lepri eta (3) 2016 & -6500 & 15.488 & 2009 & $-3 \% 5$ & $23 \% 65$ & -0.400 & 0.675 & \\
\hline Shapeda 2016 & 4.10 & 3043 & 9203 & -1.065 & 10.065 & 1.347 & 0.178 & 24 \\
\hline Dacussiseta 2017 & 6000 & 6084 & 37.013 & -5.834 & 18014 & 1.001 & 0.317 & \\
\hline MdYusofeta 2017 & 4200 & 3972 & 15.77 & -3586 & 11.965 & 1.05 & 0290 & 56 \\
\hline Serieta 2017 & 4210 & 5501 & 30.809 & -669 & 15009 & 0,758 & 0.448 & \\
\hline Dojleeta 2018 & 800 & 9.453 & 29360 & -10.52 & 26527 & 0846 & 0.397 & \\
\hline Srca eta 2018 & 6200 & 3806 & 14.485 & -1240 & 1360 & $1 . \varpi 4$ & 0.102 & \\
\hline Ducrte \& a 2019 & 4.300 & 1.360 & 1.848 & 1.65 & 6.966 & 3163 & 0.002 & 49 \\
\hline Bdacta 2019 & 2060 & 10333 & 1067709 & 0.348 & 40.82 & 1.994 & 0.046 & \\
\hline \multirow[t]{2}{*}{ Fui eta 2019} & 5900 & 6970 & 48.585 & -7.751 & 19.501 & 0846 & 0.397 & \\
\hline & 4.567 & 0.990 & 0.980 & 2627 & 6507 & 4.614 & 0.00 & \\
\hline
\end{tabular}

$R=0 \%, P=0.94$
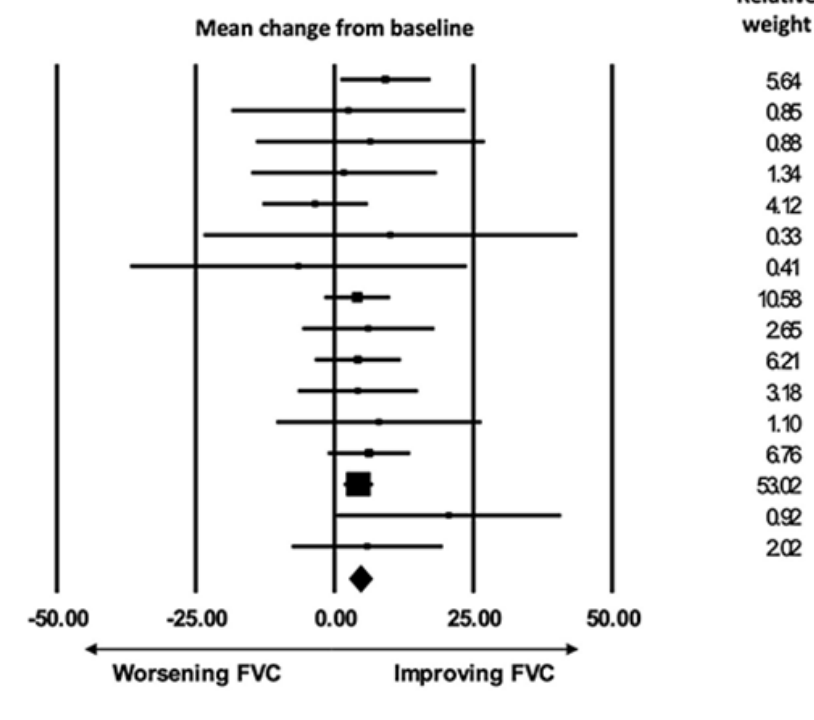

Figure 2

FVC\% Meta-analysis Forest Plot, random-effects analysis

\begin{tabular}{|c|c|c|c|c|c|c|c|c|}
\hline \multirow[t]{2}{*}{ Studyname } & \multicolumn{8}{|c|}{ Statistics for each study } \\
\hline & $\begin{array}{c}\text { Difference } \\
\text { in means }\end{array}$ & $\begin{array}{l}\text { Standard } \\
\text { error }\end{array}$ & Variance & $\begin{array}{l}\text { Lower } \\
\text { limit }\end{array}$ & $\begin{array}{c}\text { Upper } \\
\text { limit }\end{array}$ & Z-Value & p-Value & Total \\
\hline Daoussis et al 2012 & 10.880 & 4.429 & 19.613 & 2.200 & 19.560 & 2457 & 0.014 & 8 \\
\hline Keir et al 2012 & -6.170 & 9.269 & 85.920 & -24.337 & 11.997 & -0.666 & 0.506 & 6 \\
\hline Fitzgerald et al 2015 & 6.990 & 11.744 & 137.917 & -16.027 & 30.007 & 0.595 & 0.552 & 10 \\
\hline Chen et a 2016 & 7.600 & 6.353 & 40.363 & -4.852 & 20.052 & 1.196 & 0.232 & 10 \\
\hline Lepri et al (1) 2016 & 3.500 & 5.712 & $32 \approx 2$ & -7.696 & 14.66 & 0.613 & 0.540 & 8 \\
\hline Leprietal (2) 2016 & 6.000 & $2 \dddot{8}$ & 6.969 & 0.830 & 11.170 & 2274 & 0.023 & 5 \\
\hline Lepri et a (3) 2016 & 10.150 & 7.042 & 49.588 & -3.652 & 23.962 & 1.441 & 0.149 & 5 \\
\hline Sharpet al 2016 & 2100 & 2997 & 8.982 & -3.774 & 7.974 & 0.701 & 483 & 24 \\
\hline Daoussis et al 2017 & 2290 & 5.207 & 27.114 & -7.916 & 12.496 & 0.440 & 0.600 & 33 \\
\hline Md Yusof et al 2017 & 3.700 & 1.995 & 3.979 & -0.210 & 7.610 & 1.855 & 0.064 & 56 \\
\hline Dolle et a 2018 & 8.000 & 12104 & 146.511 & -15.724 & 31.724 & 0.661 & 0.509 & 9 \\
\hline Duarte et a 2019 & 5.400 & 2412 & 5.818 & 0.672 & 10.128 & 2239 & 0.025 & 49 \\
\hline Ebata \& al 2019 & 34.000 & 10.266 & 105.388 & 13.879 & 54.121 & 3.312 & 0.001 & 9 \\
\hline \multirow[t]{2}{*}{ Fu et a 2019} & 1.140 & 4.819 & 23.227 & -8.306 & 10.586 & 0.237 & 0.813 & 14 \\
\hline & 5.000 & 1.170 & 1.370 & 2.706 & 7.294 & 4.272 & 0.000 & \\
\hline
\end{tabular}

$P=10 \%, P=0.34$

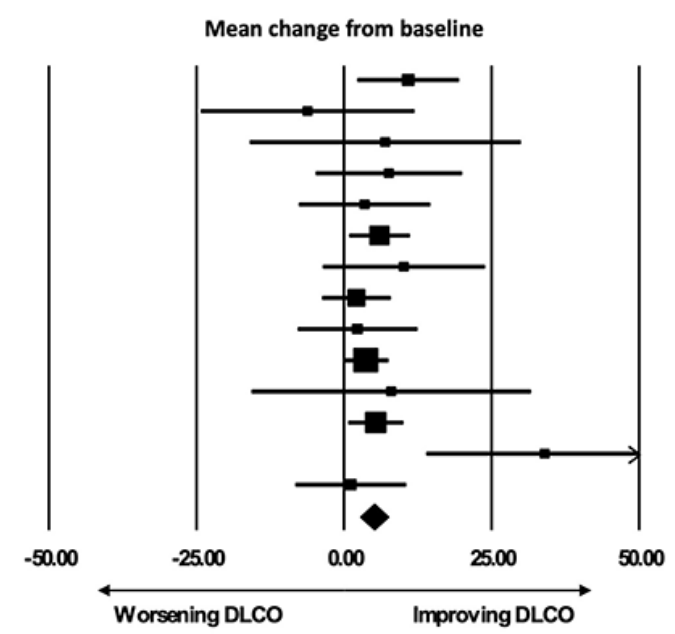

Relative

weight

6.36

1.56

0.98

3.24

3.96

15.42

266

1256

4.72

0.92

17.69

1.28
5.45

Figure 3

DLCO\% Meta-analysis Forest Plot, random effects analysis 


\section{Funnel Plot of Standard Error by Difference in means}

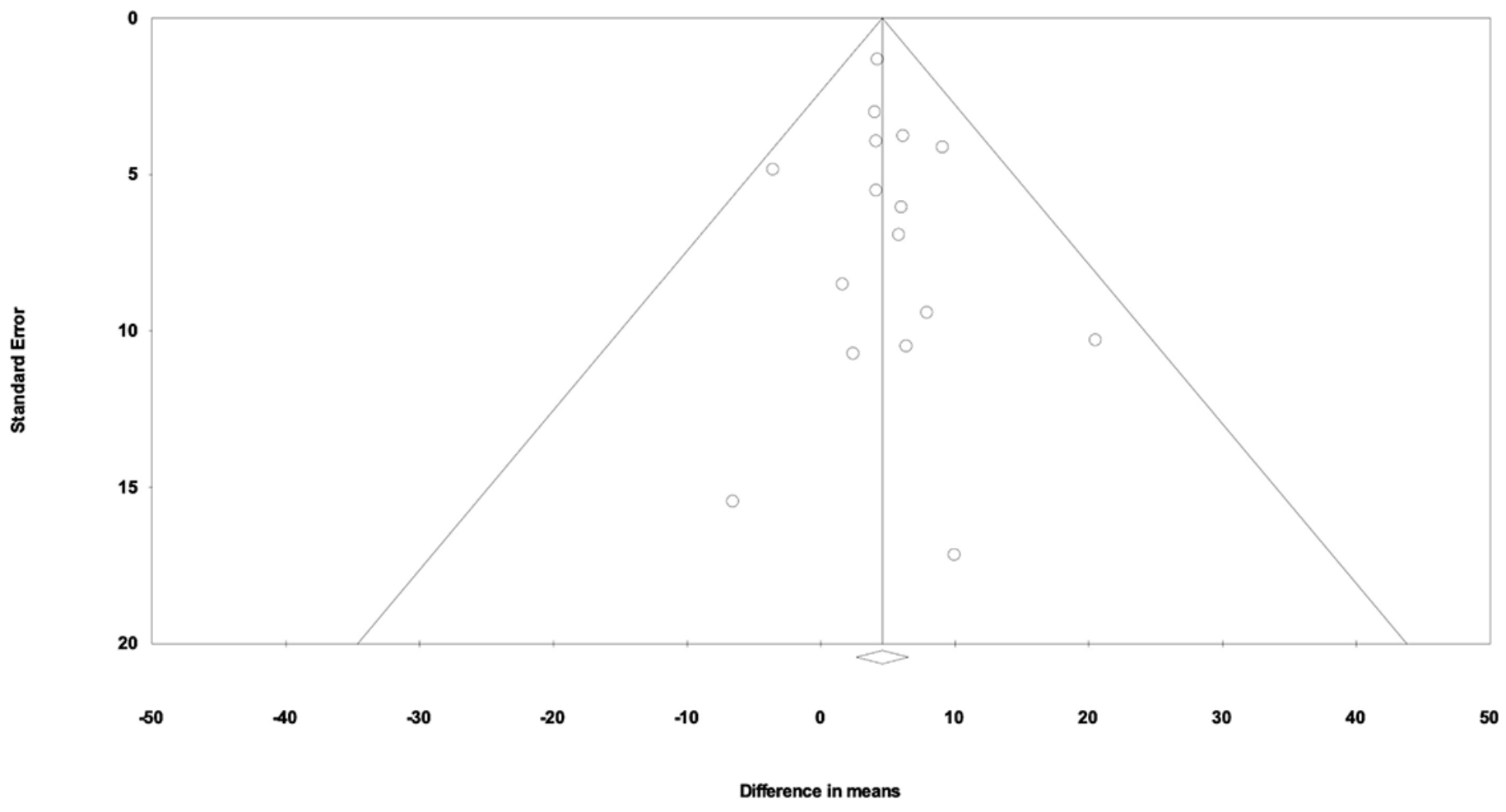

Figure 4

Funnel Plot for FVC Meta-analysis

\section{Funnel Plot of Standard Error by Difference in means}

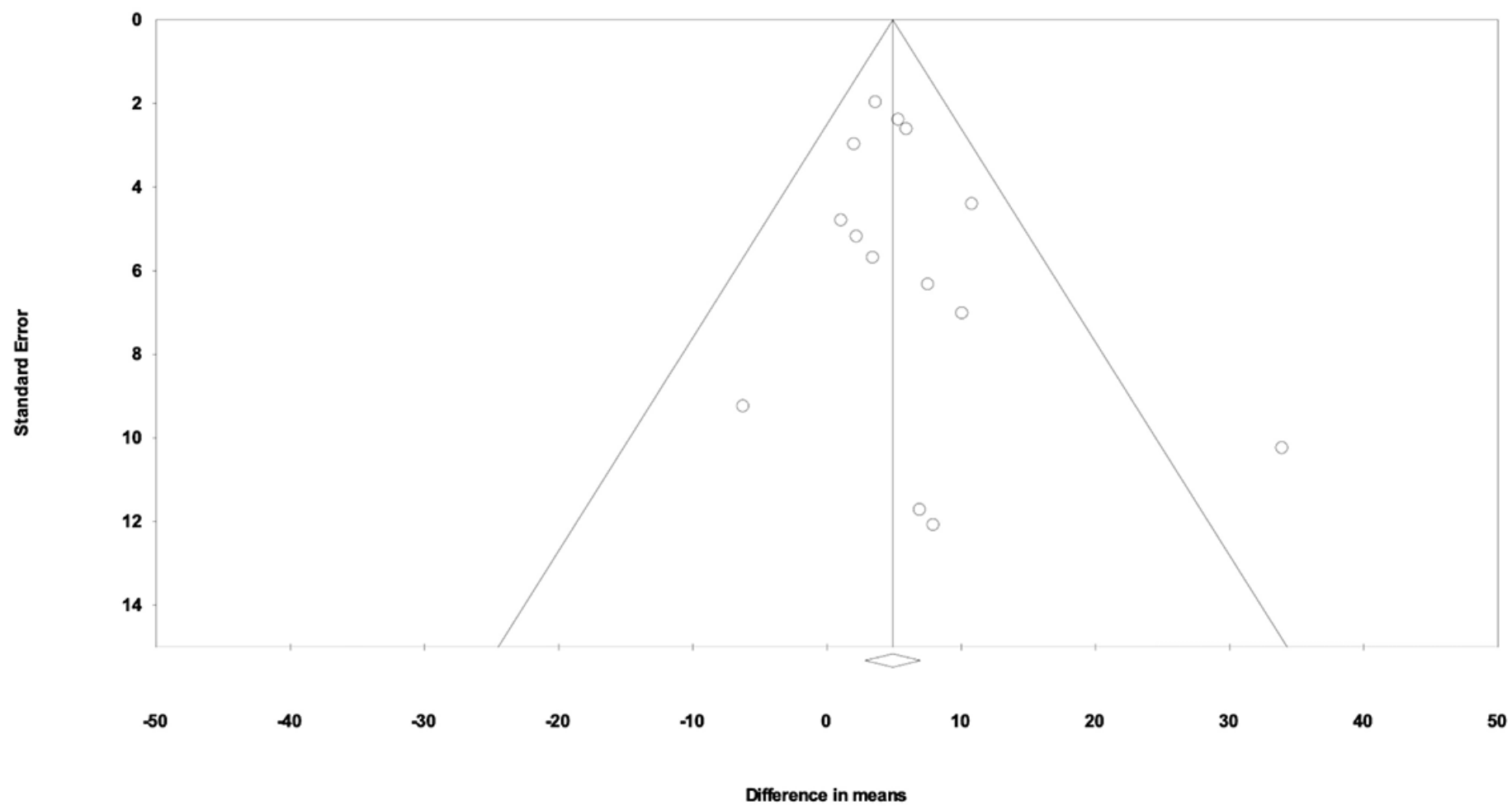


Funnel Plot for DLCO Meta-analysis

\section{Supplementary Files}

This is a list of supplementary files associated with this preprint. Click to download.

- SupplementaryTables.docx 